\title{
A New Salmonella typhimurium DNA Host Specificity
}

\author{
By C. COLSON AND ANNE M. COLSON \\ Laboratoire de Cytogénétique, Institute Carnoy, University of Louvain, \\ 24 Vaarstraat, 3000 Louvain, Belgium \\ (Accepted for publication I I September 1971)
}

SUMMARY

\begin{abstract}
The genetic properties of a new ( $h s p S$ ) host specificity of Salmonella typhimurium were investigated using bacteriophage $L$. Phage $L$ is a better substrate for s-specific restriction than phage P22. Mutants deficient in s-restriction only were found at the same frequency as mutants deficient in both restriction and modification. Crosses between $S$. typhimurium $\mathrm{Hfr}$ and $S$. typhimurium $\mathrm{F}^{-}$or between Escherichia coli and $S$. typhimurium showed that the s system has the same chromosomal location as the $\mathrm{K}$ system of $E$. coli. The s system was introduced into $E$. coli and found to be effective on phage $\lambda$.
\end{abstract}

\section{INTRODUCTION}

Escherichia coli strains $\mathrm{KI} 2$ and $\mathrm{B}$ display different host-specific restrictions and hostspecific modifications of DNA which, nevertheless, depend on very similar functions. These functions are governed by a gene cluster which has the same chromosomal location in both strains (Boyer, 1964; Wood, 1966; Glover \& Colson, 1969). Studies with merodiploids have demonstrated that some of these functions are not strain specific but can complement mutants in the corresponding gene of the other strain (Boyer \& Roulland-Dussoix, 1969; Glover, 1970). A third type of host specificity system, the A system, is present in E. coli I $_{5} \mathrm{~T}^{-}$ and was recently found to have the same chromosomal location as those of KI2 and B (Arber \& Wauters-Willems, 1970). One may reasonably expect that examination of more strains will reveal the existence of other related systems.

This paper will demonstrate such a system in strains LT7 and LT2 of Salmonella typhimurium. We report in a separate paper (Colson \& Colson, in preparation) that recombinants between Escherichia coli-Hfr and $S$. typhimurium which had inherited either the $E$. coli $\mathrm{K}$ or B system produced, after infection, a phage $P_{22}$ which plated slightly less efficiently on $S$. typhimurium than on the $E$. coli/S. typhimurium recombinant on which it had been grown. The observation that phage L, closely related to P22 (Bezdek \& Amati, I967) underwent a higher (Ioo-fold) reduction in efficiency of plating (e.o.p.) under the same conditions led us to postulate the existence of a host specificity system in $S$. typhimurium in addition to the previously studied LT system (Colson, Colson \& Van Pel, 1969; Colson, Colson \& Van Pel, 1970). By using phage $L$ as the test phage for this new system, which we have called ' $s$ ', it was possible to isolate mutants defective in $\mathrm{s}$ host specificity and to show that the genes $(h s p S$ ) for the s system have the same chromosomal location as those for the $\mathrm{K}$ system in $E$. coli. It was also found that $h s p S$ can be transferred to $E$. coli where it restricts and modifies phage $\lambda$. 


\section{METHODS}

Bacteria. The bacterial strains used in this study were derivatives of Escherichia coli KI2 and B and Salmonella typhimurium LT2 and LT7, and recombinants between $E$. coli and $S$. typhimurium LT7 (see Table I).

Bacteriophages. The Salmonella typhimurium phages used were P22 c2, a clear plaque mutant of P22 and $\mathrm{L} c$, a spontaneous clear plaque mutant of phage L (Bezdek \& Amati, 1967) received from P. Amati. The male-specific phage MS2 was used to test for the presence of the $F$ factor in bacterial strains. The notations recommended by Arber \& Linn (1969) for host specificity types and the modification carried by phages were followed throughout.

Media. The media used for the growth of Salmonella typhimurium strains and the plating of $S$. typhimurium phages have been described (Colson et al. 1969). The Escherichia coli strains were grown in L-broth, containing per litre: Difco Bacto Yeast Extract, Io g.; Difco Bacto Tryptone, Io g.; NaCl, 5 g. L-Broth solidified with I \% Difco Bacto Agar was used as bottom agar for the plating of phage $\lambda$.

Bacterial crosses. Crosses between Salmonella typhimurium $\mathrm{Hfr}$ and $\mathrm{F}^{-}$strains were performed by mixing equal volumes of exponentially growing cultures, centrifuging the cells and keeping the centrifuge tubes for $\mathrm{I} h$. at $37^{\circ}$ before resuspending the pellets. The recombinants were selected on minimal medium and purified by single colony isolation on the same medium before analysis.

Scoring of host specificity phenotypes. The restriction and modification phenotypes were determined as described previously (Colson et al. 1970). The e.o.p. of phage $\lambda$ was measured

Table I. Bacterial strains

\begin{tabular}{|c|c|c|c|}
\hline $\begin{array}{c}\text { Strain } \\
\text { number }\end{array}$ & Genotype*† & $\begin{array}{l}\text { Restriction and } \\
\text { modification } \\
\text { phenotype }\end{array}$ & Origin \\
\hline 1200 & thr leu lac & $\mathbf{r}_{\mathbf{K}}^{+} \mathrm{m}_{\mathbf{K}}^{+}$ & Escherichia coli $\mathrm{K} 12$ strain c 600 \\
\hline 1209 & thr leu lac hspK & $\mathbf{r}_{\mathbf{K}} \mathrm{m}_{\mathbf{K}}^{-}$ & From 1200 (Colson et al. 1965) \\
\hline 2000 & & $\mathrm{r}_{\mathbf{B}}^{+} \mathrm{m}_{\mathbf{B}}^{+}$ & $\begin{array}{l}\text { E. coli B strain Bc } 25 \text { I (Arber \& } \\
\text { Dussoix, I962) }\end{array}$ \\
\hline 2007 & leu, ilv serB lac hspB & $\mathrm{r}_{\mathbf{B}}^{-} \mathrm{m}_{\mathbf{B}}^{-}$ & $\begin{array}{l}\text { From } 2000 \text { (Glover \& Colson, } \\
\text { 1969) }\end{array}$ \\
\hline 4109 & & $\mathrm{r}_{\mathrm{LT}}^{+} \mathrm{m}_{\mathrm{LT}}^{+}$ & Salmonella typhimurium LT 7 \\
\hline 4233 & proC 90 & $\mathrm{r}_{\mathrm{LT}}^{+} \mathrm{m}_{\mathrm{LT}}^{+}$ & From K. Sanderson \\
\hline 4253 & proC 9 o hspLT & $\mathrm{r}_{\mathrm{LT}}^{-} \mathrm{m}_{\mathrm{LT}}^{-}$ & $\begin{array}{l}\text { From } 4233 \text { (Colson et al. } \\
\text { 1969) }\end{array}$ \\
\hline 4256 & proC 90 hspLT & $\mathrm{r}_{\mathbf{L T}}^{-} \mathrm{m}_{\mathbf{L} \mathbf{T}}^{+}$ & $\begin{array}{l}\text { From } 4233 \text { (Colson et al. } \\
\text { 1969) }\end{array}$ \\
\hline $444 \mathrm{I}$ & proC 90 thr leu hspLT hspS & $\mathrm{r}_{\mathrm{LT}}^{-} \mathrm{m}_{\mathrm{LT}}^{+} \mathrm{r}_{\mathrm{s}}^{-} \mathrm{m}_{\mathrm{s}}^{+}$ & From 4256 \\
\hline 4247 & met $A$ metE $\operatorname{trp} B$ & $\mathrm{r}_{\mathrm{LT}}^{+} \mathrm{m}_{\mathrm{LT}}^{+}$ & $\begin{array}{l}\text { S. typhimurium LT } 2 \text { strain } \\
\text { SL } 1027 \text { from B. Stocker }\end{array}$ \\
\hline 4274 & met $A$ metE $\operatorname{trp} B$ hspLT & $\mathrm{r}_{\mathrm{LT}}^{-} \mathrm{m}_{\mathrm{LT}}^{+}$ & $\begin{array}{l}\text { From } 4247 \text { (Colson et al. } \\
\text { I969) }\end{array}$ \\
\hline 4214 & $\mathrm{Hfr} \mathrm{K} 4 \operatorname{ser} A I_{3}$ & $\mathrm{r}_{\mathrm{LT}}^{+} \mathrm{m}_{\mathrm{LT}}^{+}$ & From K. Sanderson \\
\hline $\begin{array}{l}4304 \\
4321 \\
4328\end{array}$ & $\begin{array}{l}\left(m u t^{+} l e u^{+} \text {ara } h s p K^{+}\right) h s p L T \\
\left(m u t^{+} l e u^{+} \text {ara } h s p K\right) h s p L T \\
\left(m u t^{+} l e u^{+} \text {ara }^{+} p y r A \text { hspK }\right) h s p L T\end{array}$ & $\begin{array}{l}\mathrm{r}_{\mathbf{L T}}^{-} \mathrm{m}_{\mathbf{L T}}^{-} \mathrm{r}_{\mathrm{K}}^{+} \mathrm{m}_{\mathrm{K}}^{+} \\
\mathrm{r}_{\mathbf{L T}}^{-} \mathrm{m}_{\mathbf{L T}}^{+} \mathrm{r}_{\mathbf{K}}^{-} \mathrm{m}_{\mathrm{K}}^{+} \\
\mathrm{r}_{\mathbf{L T}}^{-} \mathrm{m}_{\mathbf{L T}}^{-} \mathrm{r}_{\mathbf{K}}^{-} \mathrm{m}_{\mathbf{K}}^{+}\end{array}$ & $\begin{array}{l}\text { E. coli } \times S \text {. typhimurium } \\
\text { recombinants } \\
\text { (Colson \& Colson, in } \\
\text { preparation) }\end{array}$ \\
\hline
\end{tabular}


with indicator bacteria grown in L-broth plus $0.2 \%$ maltose and starved for $\mathrm{I}$ h. at $37^{\circ}$ in $0.01 \mathrm{M}-\mathrm{MgSO}_{4}$ prior to phage infection. The phages were preadsorbed for $15 \mathrm{~min}$. before plating.

\section{RESULTS}

Mutants of the S system. Restriction-deficient mutants of the s system were isolated by the same methods as those used previously for the isolation of mutants in the LT system (Colson et al. 1969). About $\mathrm{I} \times 10^{3}$ cells from nitrosoguanidine treated cultures were plated together with $\mathrm{I} \times 10^{5}$ particles of $\mathrm{L} c . \mathrm{K}$ (grown on a recombinant possessing the $\mathrm{K}$ system of Escherichia coli). The plates were examined for infected colonies, recognizable by their nibbled appearance, which were restreaked and tested for the capacity to exercise s restriction and modification. About half of them were found to lack either the $\mathrm{s}$ restriction only or both $\mathrm{s}$ restriction and modification. More mutants were then isolated by using phage $\mathrm{L} c$. $\mathrm{O}$ (grown on a mutant lacking the $\mathrm{s}$ modification). Some mutants were found also among clones successfully infected with F-lac ${ }^{+}$after mating with $E$. coli but this method was less effective than it was in selecting mutants in the LT system, probably because $\mathrm{S}$ restriction reduces the frequency of F-lac infection much less than does LT restriction.

Among 2 I mutants isolated independently (Table 2), II had lost both $\mathrm{S}$ restriction and modification $\left(r_{s}^{-} m_{s}^{-}\right)$while $r o$ had lost only the $s$ restriction $\left(r_{s}^{-} m_{s}^{+}\right)$. Some $r_{s}^{-} m_{s}^{-}$mutants were obtained in strains which already lacked the $\mathrm{LT}$ restriction and modification thus making it possible to demonstrate the independent action of the $\mathrm{S}$ and LT restrictions on phages without the use of recombinants between Escherichia coli and Salmonella typhimurium. Table 3 shows the results of this analysis for phages $\mathrm{P} 22$ and $\mathrm{L}$. When these phages lack $\mathrm{S}$ modification they exhibit the same reduction in e.o.p. on a $r_{S}^{+} m_{S}^{+} r_{L T}^{-} m_{L T}^{-}$strain as phage with the B or K modification. Thus this reduction of e.o.p. results from the absence of the s modification and not from the presence of an $E$. coli modification. It appears also that the $s$ and LT restrictions are additive: the restriction coefficient of phage $L . O$ is higher on a strain exercising both restrictions than on strains exercising only $\mathrm{S}$ or LT restriction. Nevertheless, the restriction coefficient of $\mathbf{P} 22.0$ by a strain exercising both $\mathrm{S}$ and LT restrictions is not lower than that of L.O in spite of the fact that P22 DNA is a poor substrate for the $\mathrm{S}$ restriction. This seems to be caused by a lower sensitivity of phage L to the LT restriction.

Chromosomal location of the s system. Since recombinants which inherited the $\mathrm{K}$ or $\mathrm{B}$ hsp genes lost the hspS genes, it is most likely that both sets of genes have the same chromosomal location, that is, one minute on the left of the marker thr. To confirm this a thr leu proC

\section{Table 2. Restriction-deficient mutants in the s system of Salmonella typhimurium}

The mutants from experiments $I$ to 3 were isolated among colonies infected by phage after plating about $\mathrm{I} \times 10^{3}$ cells from nitrosoguanidine treated cultures with $\mathrm{I} \times 10^{5}$ particles of $\mathrm{L} c$. LT. The mutants from experiments 4 to 7 were isolated among colonies which had inherited an F-lac ${ }^{+}$from Escherichia coli.

$\begin{array}{cc}\begin{array}{c}\text { Experiment } \\ \text { number }\end{array} & \text { Strain } \\ \text { I } & 4233 \mathrm{LT} 7 \mathrm{r}_{\mathrm{LT}}^{+} \mathrm{m}_{\mathrm{LT}}^{+} \\ 2 & 4214 \mathrm{LT} 2 \mathrm{r}_{\mathrm{LT}}^{+} \mathrm{m}_{\mathrm{LT}}^{+} \\ 3 & 4274 \mathrm{LT} 2 \mathrm{r}_{\mathrm{LT}}^{-} \mathrm{m}_{\mathrm{LT}}^{+} \\ 4 & 4109 \mathrm{LT} 7 \mathrm{r}_{\mathrm{LT}}^{+} \mathrm{m}_{\mathrm{LT}}^{+} \\ 5 & 4253 \mathrm{LT} 7 \mathrm{r}_{\mathrm{LT}}^{-} \mathrm{m}_{\mathrm{LT}}^{+} \\ 6 & 4256 \mathrm{LT} 7 \mathrm{r}_{\mathrm{LT}}^{-} \mathrm{m}_{\mathrm{LT}}^{+} \\ 7 & 4247 \mathrm{LT} 2 \mathrm{r}_{\mathrm{LT}}^{+} \mathrm{m}_{\mathrm{LT}}^{+}\end{array}$

\begin{tabular}{|c|c|}
\hline $\mathrm{r}_{\mathrm{s}}^{-} \mathrm{m}_{\mathrm{s}}^{-}$ & $\mathrm{r}_{\mathrm{s}}^{-} \mathrm{m}_{\mathrm{s}}^{+}$ \\
\hline 3 & 2 \\
\hline I & 0 \\
\hline 4 & 4 \\
\hline o & I \\
\hline 3 & I \\
\hline 0 & I \\
\hline 0 & I \\
\hline
\end{tabular}


$h s p S h p L T$ derivative of LT7 was constructed and used as recipient in a cross with Hfr $\mathrm{K} 4$ which transfers the chromosome in the order O-thr-leu-pro. The inheritance of $h s p S^{+}$was scored among various classes of recombinants selected in the thr-leu region of the map and compared to that of $h s p L T^{+}$and proC $C^{+}$. It was found (Table 4) that recombinants which inherited $t h r^{+}$but not $l e u^{+}$from the donor inherited $h s p S^{+}$at about the same frequency as $t h r^{+} l e u^{+}$recombinants whereas recombinants which inherited $l e u^{+}$but not $t h r^{+}$inherited $h s p S^{+}$much less frequently. Since the linkage of $t h r$ to leu was higher (94\%) than that of $h s p S$ to leu $(60 \%)$ it can be concluded that hspS map between the origin of $\mathrm{Hfr} \mathrm{K} 4$ and $t h r$.

The allelism of $h s p K$ and $h s p S$ was further demonstrated in two crosses between Hfr $\mathrm{K} 4$ and two recombinants of $\mathrm{LT} 7$ which inherited $\mathrm{r}_{\mathrm{K}}^{-} \mathrm{m}_{\mathrm{K}}^{+}$and ara or pyrA from Escherichia coli (Colson \& Colson, in preparation). These strains were chosen for two reasons. First, since they lacked $\mathrm{K}$ restriction but had the $\mathrm{K}$ modification ability it was possible to score the presence of the $\mathrm{K}$ system in recombinants and eliminate the restriction of Salmonella typhimurium DNA in conjugation. Secondly, the markers ara and pyrA map between $t h r$ and leu and thus are linked to $h s p S$ and $h s p K$. By selecting $a r a^{+}$and $p y r A^{+}$recombinants and analysing their host specificity phenotypes it was possible to see whether $\mathrm{K}$ modification was always lost when $h s p S^{+}$was inherited from $\mathrm{Hfr} \mathrm{K} 4$ or if recombinants could be obtained which had both systems or neither. Among $89 \mathrm{ara}^{+}$and $92 \mathrm{pyrA}^{+}$recombinants examined

Table 3. $\mathrm{S}$ and $\mathrm{LT}$ restrictions and modifications of phages $P 22$ and $L$

The restriction coefficients are expressed as the quotient of the number of plaques counted on the strain exercising no restriction (4295) divided by the number of plaques counted on each restricting host. All strains are derivatives of LT7 proC 90 (4233).

\begin{tabular}{|c|c|c|c|c|}
\hline \multirow[b]{2}{*}{ Phage } & \multicolumn{4}{|c|}{ Restriction coefficient on strain } \\
\hline & $\mathrm{r}_{\mathrm{LT}}^{-} \mathrm{m}_{\mathrm{LT}}^{-} \mathrm{r}_{\mathrm{S}}^{-} \mathrm{m}_{\mathrm{S}}^{-}$ & $\mathrm{r}_{\mathrm{LT}}^{-} \mathrm{m}_{\overline{\mathrm{LT}}}^{4253} \mathrm{r}_{\mathrm{s}}^{+} \mathrm{m}_{\mathrm{s}}^{+}$ & $\begin{array}{c}4423 \\
\mathrm{r}_{\mathrm{LT}}^{+} \mathrm{m}_{\mathrm{LT}}^{+} \mathrm{r}_{\mathrm{S}}^{-} \mathrm{m}_{\mathrm{S}}^{-}\end{array}$ & $\begin{array}{c}4233 \\
\mathrm{r}_{\mathrm{LT}}^{+} \mathrm{m}_{\mathrm{LT}}^{+} \mathrm{r}_{\mathrm{s}}^{+} \mathrm{m}_{\mathrm{s}}^{+}\end{array}$ \\
\hline $\mathrm{P}_{22 c 2} . \mathrm{O}$ & $\mathbf{I}$ & $\mathrm{I} \cdot 4$ & 10,000 & 21,700 \\
\hline P22c2.K & $\mathbf{I}$ & $2 \cdot 5$ & 21,000 & 62,000 \\
\hline P22c2.B & $\mathbf{I}$ & $\mathrm{I} \cdot 7$ & I 5,000 & 24,000 \\
\hline P22c2.S & I & I & 8,000 & 12,000 \\
\hline P22c2.LT & I & $I \cdot 6$ & I & $I \cdot 6$ \\
\hline P22c2.S,LT & $\mathbf{I}$ & I & $\mathbf{I}$ & I \\
\hline $\mathrm{Lc.O}$ & $\mathbf{I}$ & 66 & 2,000 & 23,000 \\
\hline $\mathbf{L c} . \mathbf{K}$ & $\mathbf{I}$ & 100 & 3,100 & 43,000 \\
\hline $\mathbf{L} c . \mathbf{B}$ & $\mathbf{I}$ & 83 & 2,800 & $3 I, 000$ \\
\hline Lc.S & $\mathbf{I}$ & $\mathbf{I}$ & $\mathrm{I}, 100$ & 2,200 \\
\hline Lc.LT & I & 90 & I & I 20 \\
\hline Lc.S,LT & I & I & I & I \\
\hline
\end{tabular}

Table 4. Inheritance of $h s p S^{+}, h s p L T^{+}$and proC $C^{+}$among recombinants between Salmonella typhimurium $\mathrm{Hfr}$ and $\mathrm{F}^{-}$selected in the thr leu region

$\mathrm{thr}^{+}$and $\mathrm{leu}^{+}$Recombinants were selected in a cross between Hfr $\mathrm{K} 4$ and strain 444I thr leu proC $h s p L T h s p S$. A large number of recombinants was first classified for the inheritance of $l e u^{+}$and $t h r^{+}$. About 50 recombinants of each class were scored for the inheritance of the unselected markers.

\begin{tabular}{|c|c|c|c|}
\hline \multirow[b]{2}{*}{ Class of recombinant } & \multicolumn{3}{|c|}{ Unselected marker ( $\%)$} \\
\hline & $h s p S^{+}$ & $h s p L T^{+}$ & proc $^{+}$ \\
\hline$t h r^{+} l e u^{+}$ & 60 & 23 & 25 \\
\hline$t h r+l e u$ & 54 & 4 & 2 \\
\hline thr leu $u^{+}$ & 21 & 30 & 24 \\
\hline
\end{tabular}


(Table 5) only donor and recipient type host specificity was observed. Hence it is assumed that $h s p S$ and $h s p K$ are allelic or at least very closely linked.

The s system in Escherichia coli. When restriction of incoming DNA was eliminated the exchange of $h s p S$ and $h s p K$ between Escherichia coli and Salmonella typhimurium was easy to obtain in S. typhimurium recipients either by mating $S$. typhimurium LT7 mut with $E$. coli $\mathrm{Hfr}$ (Colson \& Colson, in preparation) or by mating $\mathrm{r}_{\mathrm{K}}^{-} \mathrm{m}_{\mathrm{K}}^{+}$recombinants of $S$. typhimurium with an S. typhimurium $\mathrm{Hfr}$ (see Table 5). An attempt was made to obtain the reciprocal event, that is, the introduction of the s system into $E$. coli by mating an $S$. typhimurium $\mathrm{Hfr}$ with a restriction-deficient mutant of $E$. coli $\mathrm{KI} 2$. However, in this cross, between $h s p S^{+} \mathrm{Hfr} \mathrm{K} 4$ and $E$. coli the selected $t h r^{+} l e u^{+}$recombinants were found at a very low frequency (about $1^{10^{-7}}$ ). After single colony reisolation, 40 of them were further analysed. All were sensitive to the male-specific phage MS2 and I5 of them restricted phages $\lambda . \mathrm{K}$ and $\lambda$. B. It was therefore assumed that they were, in fact, heterogenotes carrying F-thr ${ }^{+} l e u^{+}$factors from $\mathrm{Hfr} \mathrm{K} 4$ and that some of them had in addition the genes for the $\mathrm{s}$ system. This conclusion was confirmed by the observation that one of them transferred $t h r^{+} l e u^{+}$together with the s system to both E. coli and S. typhimurium strains. In an S. typhimurium thr leu $\mathrm{r}_{\mathrm{s}}^{-} \mathrm{m}_{\mathrm{s}}^{+}$recipient, the transfer of $t h r^{+} l e u^{+}$was accompanied by s restriction in all MS2-sensitive recombinants thought to have received the whole F-prime factor and in half of the MS2-resistant recombinants which had integrated the $t h r^{+} l e u^{+}$part of it. After the transfer of the F-thr+leu ${ }^{+} h s p S^{+}$factor to an $\mathrm{r}_{B}^{-} \mathrm{m}_{B}^{+}$ strain, one recombinant was $\mathrm{MS}_{2}$ resistant and lacked в modification ability but inherited the $\mathrm{s}$ system. This recombinant remained stable in respect of the $\mathrm{s}$ restriction and modification and had most probably integrated the $h s p S$ genes in place of its original $h s p B$ genes. The stability of this strain permitted precise measurement of the action of the s system on the e.o.p. of phage $\lambda$. It was found (Table 6) that in E. coli the restriction coefficient of the $\mathrm{s}$ system on phage $\lambda$ was much higher than that on phages P22 and L in S. typhimurium and was even higher than those of the $\mathrm{K}$ and $\mathrm{B}$ systems.

Table 5. Host specificity in recombinants from crosses between Salmonella typhimurium Hfr and strains with the $\mathrm{K}$ system of Escherichia coli

Derivatives of LT7 mut which had inherited $m u t^{+} l e u^{+} h s p K$ and either ara or pyr $A$ from $E$. coli were crossed with $\mathrm{Hfr} \mathrm{K4}$; $\mathrm{ara}^{+}$and $p y r \mathrm{~A}^{+}$recombinants were selected, restreaked on the selective media and scored for their restriction and modification phenotypes.

\begin{tabular}{lccc} 
& & \multicolumn{2}{c}{$\begin{array}{c}\text { Number of recombinants with } \\
\text { phenotype }\end{array}$} \\
Recipient strain & Selected marker & $\overbrace{\mathrm{K}}^{-} \mathrm{m}_{\mathrm{K}}^{+}$ & $\mathrm{r}_{\mathrm{S}}^{+} \mathrm{m}_{\mathrm{S}}^{+}$ \\
$432 \mathrm{I}$ ara $\mathrm{r}_{\mathrm{K}}^{-} \mathrm{m}_{\mathrm{K}}^{+}$ & ara $^{+}$ & 32 & 57 \\
4328 pyrA $\mathrm{r}_{\mathrm{K}}^{-} \mathrm{m}_{\mathrm{K}}^{+}$ & pyrA $^{+}$ & 13 & 79
\end{tabular}

Table 6. $\mathrm{K}, \mathrm{B}$ and $\mathrm{s}$ restrictions and modifications of phage $\lambda$

The restriction coefficients were calculated as in Table 3. The test strains were derivatives of Escherichia coli $\mathrm{K} 12$ and B. Strain 2026 has the $h s p S^{+}$genes from Salmonella typhimurium.

\begin{tabular}{|c|c|c|c|c|}
\hline \multirow[b]{2}{*}{ Phage } & \multicolumn{4}{|c|}{ Restriction coefficient on strain } \\
\hline & $\begin{array}{l}1209 \\
\mathrm{r}_{\mathbf{K}}-\mathrm{m}_{\overline{\mathrm{K}}}\end{array}$ & $\begin{array}{c}1200 \\
\mathrm{r}_{\mathbf{K}}^{+} \mathrm{m}_{\mathbf{K}}^{+}\end{array}$ & $\begin{array}{l}2000 \\
\mathrm{r}_{\mathbf{B}}^{+} \mathrm{m}_{\mathbf{B}}^{+}\end{array}$ & $\begin{array}{r}2026 \\
\mathrm{r}_{\mathrm{s}}^{+} \mathrm{m}_{\mathrm{s}}^{+}\end{array}$ \\
\hline$\lambda .0$ & $\mathbf{I}$ & I,800 & 6,000 & 100,000 \\
\hline$\lambda . \mathbf{K}$ & $\mathbf{I}$ & I & 2,200 & 5,500 \\
\hline$\lambda . \mathbf{B}$ & I & 1,400 & I & 36,000 \\
\hline$\lambda . S$ & $\mathbf{I}$ & 2,500 & 5,000 & I \\
\hline
\end{tabular}




\section{DISCUSSION}

Salmonella typhimurium exercises two independent host specificity systems of DNA restriction and modification. Since both systems are present in LT7 and LT2, it was not possible to detect their activities by transfer of DNA between these strains. However, they could be identified by means of recombinants between Escherichia coli and S. typhimurium LT7 mut which lacked the genetic determinants for them while still remaining sensitive to the Salmonella phages P22 and L. Mutations in the Salmonella host specificity systems could then be characterized and mapped in Salmonella $\times$ Salmonella crosses.

One of these host specificity systems, which we have designated LT (Colson \& Colson, I967) was first detected by Zinder (I960). It is governed by genes ( $h s p L T$ ) situated near pro (Colson et al. 1970) and has no known equivalent in Escherichia coli. We have shown that the second system, discovered only recently (Colson \& Colson, in preparation) is governed by genes ( $h s p S$ ) situated at the same locus as the $h s p K$ and $h s p B$ genes in $E$. coli K 2 and B. It is thus likely that the $\mathrm{K}$, B and $\mathrm{S}$ systems together with the A system, which occupies this chromosomal locus in E. coli I $\mathrm{T}^{-}$, (Arber \& Wauters-Willems, I970), evolved from a common ancestor and differ principally in the sequence of nucleotides which they each recognize on DNA.

Complementation studies between temperature-sensitive mutants in the $h s p$ genes of Escherichia coli $\mathrm{KI} 2$ and B strongly suggest that the products of these genes act as oligomeric enzymes (Hubacek \& Glover, 1970). Since complementation studies also showed that some mutations in the B system could be complemented by the equivalent gene product of the $\mathrm{K}$ system and vice versa (Boyer \& Roulland-Dussoix, I969; Glover, I970), the polypeptides coded by the $h s p K$ and $h s p B$ genes can interact to constitute functional enzymes. Whether the polypeptides coded by the $h s p S$ genes, present in a less closely related organism, have the capacity to interact with the $h s p$ gene products of the systems studied in $E$. coli is an open question. The work described here provides nearly all the tools necessary for such a study which is now in progress.

\section{REFERENCES}

Arber, W. \& DussoIx, D. (1962). Host specificity of DNA produced by Escherichia coli. I. Host controlled modification of bacteriophage $\lambda$. Journal of Molecular Biology 5, 1 8-36.

Arber, W. \& Linn, S. (I969). DNA modification and restriction. Annual Review of Biochemistry 38, 467-500.

Arber, W. \& Wauters-Willems, D. (1970). Host specificity of DNA produced by Escherichia coli. XII. The two restriction and modification systems of strain 15 $^{-}$. Molecular and General Genetics 108, $203-217$.

Bezdek, M. \& Amati, P. (1967). Properties of P 22 and a related Salmonella typhimurium phage. I. General features and host specificity. Virology 3r, 272-278.

BOYER, H. W. (1964). Genetic control of restriction and modification in Escherichia coli. Journal of Bacterio$\log y 88,1652-1660$.

BOYER, H. W. \& Roulland-Dussoix, D. (1969). A complementation analysis of the restriction and modification of DNA in Escherichia coli. Journal of Molecular Biology 4I, 459-472.

Colson, C. \& Colson, A. M. (1967). Host specificity and fertility in Salmonella typhimurium LT 7. Biochemical and Biophysical Research Communications 29, 692-695.

Colson, A. M., Colson, C. \& Van Pel, A. (1969). Host-controlled restriction mutants of Salmonella typhimurium. Journal of General Microbiology 58, 57-64.

Colson, C., Colson, A. M. \& VAn Pel, A. (1970). Chromosomal location of host specificity in Salmonella typhimurium. Journal of General Microbiology 6o, 265-27I.

Colson, C., Glover, S. W., Symonds, N. \& Stacey, K. A. (1965). The location of the genes for hostcontrolled modification and restriction in Escherichia coli KI2. Genetics 52, I043-1050.

Glover, S. W. (1970). Functional analysis of host specificity mutants in Escherichia coli. Genetical Research I5, 237-250. 
Glover, S. W. \& COlson, C. (1969). Genetics of host-controlled restriction and modification in Escherichia coli. Genetical Research 13, 227-240.

HubaceK, J. \& Glover, S. W. (1970). Complementation analysis of temperature sensitive host specificity mutations in Escherichia coli. Journal of Molecular Biology 50, I1 I-I 27.

TAYLOR, A. L. \& TROTTER, C. D. (1967). Revised linkage map of Escherichia coli. Bacteriological Reviews 31, $332-353$.

WooD, W. B. (1966). Host specificity of DNA produced by Escherichia coli: bacterial mutations affecting the restriction and modification of DNA. Journal of Molecular Biology 16, i $18-133$.

ZINDER, N. D. (1960). Hybrids of Escherichia and Salmonella. Science, New York 131, 813-815. 